\title{
NO EXÍLIO ENTRE O DESEJO E O SONHO: SOBRE A "POÉTICA UTÓPICA" DE MOACYR FÉLIX
}

http://dx.doi.org/10.11606/issn.2237-1184.v0i28p264-283

Diogo César Nunes

UNIABEU Centro Universitário

PALAVRAS-CHAVE:

O presente texto propõe uma leitura da obra de Moacyr Félix partindo da indicação de que sua "poética utópica" trava interlocução com a Teoria Crítica da Sociedade e com a Filosofia de Ernst Bloch. Busca explorar na figura do "exílio" a possibilidade de uma leitura da subjetividade e da realidade que põe em "crise" tanto a imagem do futuro (sonho utópico) quanto a de si. Em aproximação à psicanálise, sugere que sua poética "utópica" pode ser lida como uma poética do "desamparo", que, ao duvidar tanto da imagem quanto da possibilidade de dizer a "palavra exata", dá acesso à "verdade impossível" do desejo.

\section{ABSTRACT}

This paper proposes a reading of Moacyr Félix's poems starting from the warning that his "utopian poetics" is in interlocution with the Critical Theory of the Society and with the Philosophy of Ernst Bloch. It seeks to explore, by the "exile", the possibility of a reading of subjectivity and of reality that puts in "crisis" both the image of the future (utopian dream) and of itself. Finally, in an approach to psychoanalysis, the article suggests that its "utopian" poetics can be read as a "helpless" poetic, which, by doubting both the image and the possibility of saying "exact word", gives access to "truth impossible" of desire.

\section{Utopia;}

Moacyr Félix;

Poética utópica;

Exílio;

Desamparo.

\section{KEYWORDS}

Utopia;

Moacyr Félix;

Utopian poetics;

Exile;

Helplessness. 
Pela recusa intransigente da aparência de reconciliação, a arte mantém a utopia no seio do irreconciliável. ${ }^{1}$

presente artigo tem como objetivo promover uma leitura da obra poética de Moacyr Félix tomando como referência o tema da utopia, e, em específico, o que seria a "crise" da representação de uma imagem idealizada de futuro. Buscaremos apresentar algumas premissas que se refiram tanto ao aporte teórico desta leitura quanto à análise do seu objeto, na intenção de oferecer embasamento, também, às hipóteses centrais do trabalho, quais sejam, a de que o utópico prescinde de uma projeção otimista do futuro e a de que a poesia de Félix pode ser lida como uma "poética utópica" que busca, mas não encontra, "amparo" nem em inspirações em um passado pré-capitalista nem em imagens que fixem, ou orientem, aspirações em relação ao porvir. Assim, serão acionados poemas de Félix, publicados em distintas obras (dos anos 1950 até a década de 1990), que permitam entrever suas interlocuções com a Filosofia da Esperança de Ernst Bloch e com a Teoria Crítica de T. W. Adorno. Por fim, será posto em questão se a recusa a um "amparo imaginário" não seria uma forma de fazer falar o desejo, hipótese que confrontaria a tese da poesia de Félix como pertencente ao "romantismo revolucionário", noção que abarcaria a heterogeneidade da dita "arte engajada" brasileira dos anos 1950 e 60.

Como afirmou Henrique Estrada Rodrigues, embora a noção de "poética utópica" seja polissêmica, ela demanda uma especificidade própria, compreendida, pelo autor, a partir de três "critérios de avaliação": "o conhecimento de sua historicidade, a análise de seus textos constitutivos e o reconhecimento de diferentes modalidades de elaboração e interpretação do imaginário utópico" ${ }^{2}$. Em relação à obra de Moacyr Félix, cremos acessar tais critérios, ao menos inicialmente, através da indicação de Luiz Carlos Lima, quando afirmou que a "poética utópica" de Félix "torna-se o espelho de uma unidade dialética entre verdade e utopia, que traduz uma tensão permanente na busca da verdade não-reconciliada num mundo reconciliado com a não-verdade

\footnotetext{
${ }^{1}$ ADORNO, T. W. Teoria Estética. Lisboa: Edições 70, 1982, p. 58.

2 RODRIGUES, Henrique Estrada. A Utopia no Tempo, o Tempo na Utopia. Texto apresentado no Fórum de Teoria e História da Historiografia, UFRRJ, ago. 2015, p. 4.
} 
da vida mutilada" ${ }^{3}$. Neste mesmo texto, publicado à ocasião do falecimento de Félix, em 2005, Carlos Lima disse que tal "poética da utopia tem como base conceitual a obra de Ernst Bloch, Walter Benjamin e Theodor Adorno". É possível que, na primeira frase citada no texto, a noção de "vida mutilada" faça referência ao termo beschädigten Leben traduzido recentemente por Gabriel Cohn como "vida danificada" -, que aparece no subtítulo da obra Minima Moralia, de Theodor W. Adorno". O esclarecimento desta "base conceitual" nos orienta a leitura que intentamos promover da poesia de Félix, de modo que a afirmativa de que sua "poética utópica" lide com o problema da "verdade nãoreconciliada num mundo reconciliado com a não-verdade" nos sugira sua intenção de se inserir no cerne de uma discussão, que remonta à apropriação hegeliana por parte da Teoria Crítica, acerca da reconciliação (entre homem e natureza, entre realidade e verdade, entre a efetividade e a universalidade do conceito), e que tem como objeto privilegiado o estatuto da obra de arte na modernidade. Para a Teoria Crítica, de um modo geral, a Utopia sinaliza à possibilidade da reconciliação - ou à liberdade como possibilidade.

Em Ernst Bloch, o sonho utópico diz respeito à possibilidade de superação, no futuro, do presente. A utopia parece querer "enxergar bem longe", disse Bloch, "mas, no fundo, apenas para atravessar a escuridão [...] do instante que acabou de ser vivido, em que todo devir [Seiende] está à deriva e oculto de si mesmo" 5 . O que Pierre Furter, em livro dedicado à filosofia blochiana, chamou de "dialética da Esperança", segue o curso, ou o processo, guiado pelo sonho utópico (ou diurno): desde a carência, abrindo a realidade a "possibilidades", até um possível-real6. A carência é sinal da presença do desejo - "desejo que nunca adormece"7 - a revelar, no presente, a sua precariedade, ou seja, naquilo "que é", o que "não-é". Assim, o sonho fala, antes de mais nada, do presente, mas de um presente em que insiste o desejo, sinal daquilo que, em latência, "não é", "não foi" ou "não veio-a-ser". Ao oferecer uma imagem ao desejo, o sonho utópico faz do estado presente um estado de carência e, ao mesmo tempo, eleva aquela latência à condição de potência: o que falta passa a apontar ao futuro, ao que "ainda-não veio-a-ser".

Se a imagem do futuro aponta ao por-vir, o faz "desde" o presente, que passa a ser, a um tempo, precário e "saturado de agoras" 8 . Assim, a

\footnotetext{
${ }^{3}$ LIMA, Carlos. Poesia e Utopia em Moacyr Félix. Letras \& Letras, v. 21, n. 2, 2005, p. 10.

${ }^{4}$ ADORNO, Theodor W. Minima Moralia. Rio de Janeiro: Azougue, 2008.

${ }^{5} \mathrm{BLOCH}$, Ernst. O Princípio Esperança. Vol. 1. Rio de Janeiro: Ed. UERJ; Contraponto, 2005, p. 23.

${ }^{6}$ FURTER, Pierre. Dialética da Esperança. Rio de Janeiro: Paz e Terra, 1974, p. 80.

${ }^{7}$ BLOCH, Ernst. op. cit., p. 79.

${ }^{8}$ Tomamos tal expressão de Benjamin, que, na $14^{\text {a }}$ das teses Sobre o conceito de história, afirmou que "A história é objeto de uma construção cujo lugar não é o tempo homogêneo e vazio, mas um tempo saturado de 'agoras'" (BENJAMIN, Walter. Magia e Técnica, Arte e Política. Obras
} 
realidade se des-totaliza, por assim dizer, se revelando como inacabada, pendente. Para Bloch, é exatamente pelas brechas da realidade presente que o sonho se infiltra ${ }^{9}$, oferecendo ao presente o futuro enquanto possibilidade - o tempo histórico, em suma, como aberto à práxis. $\mathrm{O}$ sonho utópico, ou diurno, investe, deste modo, a realidade de temporalidades: atualiza sonhos já sonhados - e, tomando referência na formulação de Kojève, "desejos desejados"10 - a partir da sua situação histórica atual, desdobrando o tempo presente em "possíveis-reais". No poema No perguntar de um agora, Félix teria formulado tal questão, todavia enfatizando o caráter dialético e negativo do desejo em relação ao existente (ao que é): “O poema novo é tão velho como a revolta que fecunda / o som futuro da humanidade no ventre antigo / do desejo que nega o que é e movimenta a antítese / da rua, da lei, do medo e do costume"11.

Se a imagem da Utopia seria, em Bloch, aquela da reconciliação ${ }^{12}$, em Félix, de acordo com Carlos Lima, a "unidade dialética entre verdade e utopia" está situada exatamente na suspensão - ou, na crise da possibilidade - da reconciliação, assumindo um caráter essencialmente negativo. Ainda que tivesse recorrido a Bloch, em distintas ocasiões, para embasar sua compreensão de utopia ${ }^{13}$, talvez tenha sido Adorno seu

Escolhidas I. São Paulo: Brasiliense, 1994, p. 229). Em Bloch, a afirmativa de que a realidade "é a mediação vastamente ramificada entre o presente, o passado pendente e sobretudo o futuro possível" (BLOCH, Ernst. op. cit., p. 194).

9 "Pois o sonho não para se se infiltrar nas lacunas" (BLOCH, Ernst. op. cit., p. 37). Novamente aproximando Bloch e Benjamin, vale lembrar a passagem, ora citada através de Rouanet, que diz: "nossa existência diurna é um país cheio de lugares ocultos em que desaguam os sonhos" (Benjamin apud ROUANET, Sérgio Paulo. As Razões do Iluminismo. São Paulo: Cia. das Letras, 1987, p. 118).

10 Para Alexandre Kojève, a noção de "desejo", conforme na Fenomenologia do Espírito, é central para a formulação hegeliana de homem (ao menos a do "primeiro Hegel") que não é somente consciência, mas possibilidade de consciência de si (o que desnaturaliza a condição humana; desloca-a do registro meramente biológico): “A realidade humana, diferente da realidade animal, só se cria pela ação que satisfaz tais desejos: a história humana é a história dos desejos desejados" (KOJÈVE, Alexandre. Introdução à leitura de Hegel. Rio de Janeiro: Contraponto, 2002, p. 13).

${ }^{11}$ FÉLIX, Moacyr. Em Nome da Vida. Rio de Janeiro: Civilização Brasileira, 1981, p. 109.

12 Acerca da relação entre a Utopia concreta e a imagem do mundo reconciliado, conferir, por exemplo, a passagem que diz que "[...] o lugar da efetivação" do utópico "situa-se unicamente no front do processo histórico e tem diante de si, num primeiro momento, preponderantemente a possibilidade real indireta. Esta, como um correlato real-objetivo, fica sendo o que corresponde à antecipação exata, à utopia concreta. Ela o é no mesmo sentido em que o concretamente utópico constitui um real-objetivo grau de realidade no front do mundo acontecendo: como ainda-não-ser da 'naturalização do ser humano, humanização da natureza'. Correspondentemente, o reino da liberdade assim caracterizado não assume a forma do retorno, mas do êxodo - ainda que para a terra sempre almejada, prometida pelo processo" (BLOCH, Ernst. op. cit., p. 202-203).

${ }^{13}$ Cf. FÉLIX, Moacyr. O Pensar e o Sentir na Obra de Moacyr Félix. Rio de Janeiro: Fundação Biblioteca Nacional; Bertrand Brasil, 2002. 
principal interlocutor. Em Adorno, o estatuto de verdade é conferido tanto à liberdade (ou à "emancipação") quanto ao desacordo entre realidade e pensamento, ou seja, justamente como o que escapa às formulações lógicas e à realidade objetiva/empírica, ora, como contraponto à instrumentalização do mundo guiada pela racionalidade esclarecida. Conforme nos diz Enio Muller, em Adorno a verdade da utopia reside na não verdade da realidade, e, assim, verdade e utopia se aludem e se sustentam no escape ao evidente e à realidade empírica, resistindo à reificação. Neste sentido, "o que é ansiado reveste-se de imagens e conceitos, sem deixar de se mostrar resiliente a toda nominação ou imageação. Sua existência é, ao mesmo tempo, sinal de presença e de ausência"14.

A reconciliação jaz como verdade na medida em que resiste à captura por um conceito, uma imagem ou uma formulação; em outros termos, na medida em que é capaz de apontar (ainda que através de um conceito, de uma imagem ou de uma formulação) para-além da realidade evidente: para o que falta e/ou o que excede "nos" próprios dispositivos que a tornam presente como possibilidade ${ }^{15}$. É possível acessar tal questão em Canto para as transformações do homem - livro escrito nas semanas seguintes ao Golpe de 1964, em que confronta a pergunta, feita por seu filho, "o que é liberdade?" -, na medida em que Félix ensaia várias respostas à interrogação sobre a liberdade, mas sempre a mantendo como enigma. Estaria ali, na negativa à definição conceitual, a possibilidade mesma da liberdade. Há um "mistério maior" no homem, escreveu em 1964, que faz dele "a espessa liberdade [...] de ser / a pátria sem fim do ato livre / que arranca a vida e o tempo e as coisas / do espelho imóvel dos conceitos" 16 .

Pode-se afirmar que o tema da liberdade se impõe em toda a obra poética de Moacyr Félix, viabilizado, todavia, através de outras noçõesenigmas - talvez caiba dizer imagens-enigmas, ou, na expressão do próprio Félix17, "irrespondíveis esfinges" - como "vida", "morte", "rosto", "voz", "tempo", "sonho". Contudo, se há um "mote" central no conjunto da sua produção seria a reflexão permanente e insistente sobre a própria poesia; em outros termos, sustentamos que seja a poesia, o fazer poético e a condição do poeta no mundo moderno, os "objetos" privilegiados do seu trabalho. Elevada à condição de premissa, tal suspeita faz atravessarem política e estética (ou política, filosofia e

\footnotetext{
${ }^{14}$ MUELLER, Enio. Filosofia à sombra de Auschwitz. São Leopoldo: Sinodal/EST, 2009, p. 186-187.

${ }^{15}$ Cf. NUNES, Diogo C. O sujeito que resta. Revista Nós - Cultura, Estética e Linguagens, Goiânia, v. 1, n. 2, 2016.

16 FÉLIX, Moacyr. Canto para as transformações do homem. Rio de Janeiro: Civilização Brasileira, 1964, p. 75-76.

17 Id. O Pensar e o Sentir na Obra de Moacyr Félix. Rio de Janeiro: Fundação Biblioteca Nacional; Bertrand Brasil, 2002, p. 82-83.
} 
poética), pondo-nos diante daquela que talvez seja a questão basilar não somente da poesia moderna, mas da arte moderna, como um todo, concentrada no par "crise" e "crítica" da representação18. Em um poema decididamente "político" como Invenção de Crença e Descrença, em que Félix insiste na exigência de "destruir o mundo", as "auroras" estão asiladas e escondidas "no mais obscuro canto das palavras", de modo que, após sofrer a "terrível dor de essências [...] à beira de tudo o que não foi mas devia ter sido", ele conclui com os seguintes versos: "Ah, construir o mundo // o mundo em que o homem possa / ser o seu poema, a sua libertação / maior"19.

A correlação entre "poema" e "libertação maior" seria mais que uma metáfora, mas indício de que o vínculo entre poesia e utopia se dê não em uma relação entre forma e conteúdo, mas, ao contrário, no processo mesmo de deslocamentos que ambas instituem em relação ao existente, uma vez que "a atividade do poema é colocar em dificuldade o signo" 20 . Ao pôr o signo em dificuldade, ou em crise, o poema suspende o significado como "alguma outra coisa", nunca garantido, sempre perdido, ou deslocado, na "cadeia significante": o lugar da verdade é um "lugar-outro", nunca jádado tampouco "em-si", que insiste no próprio presente, no próprio significante e na sua materialidade (no seu "mais obscuro canto", como escreveu Félix). Assim, seu acesso é sempre parcial e inclinado ao equívoco, permitido unicamente por uma brecha aberta pelo desencaixe estrutural que relaciona enunciado e enunciação; dada a ler como uma "imagem vaga-lume", que relampeja num instante para depois se perder

18 Para Nelson Brissac Peixoto, a crise da representação na arte está ligada diretamente à compreensão da modernidade como crise: "[...] justamente quando se começa a tomar as mercadorias por elas próprias, a arte moderna passa a tomar as obras por si mesmas, as formas e cores como forças; plano, fundo, suporte e materiais subvertidos num espaço recriado. A crise da representação atinge então também a arte" (PEIXOTO, Nelson Brissac. A Sedução da Barbárie. São Paulo: Brasiliense, 1982, p. 11-12). Na Teoria da vanguarda, Peter Bürger aponta à tendência formalista da ate moderna já desde a segunda metade do século XIX: "O lado conteudístico da obra de arte, sua 'mensagem', cada vez se retrai frente ao formal, que se cristaliza como sendo o estético em sentido mais estrito" (BÜRGER, Peter. Teoria da Vanguarda. São Paulo: Cosac Naify, 2012, p. 48). O "formalismo" da arte moderna não seria uma celebração da forma pela forma, mas a tematização da distância entre arte e realidade, de modo que o objeto "de" arte passe a ser objeto privilegiado "da" arte (GREENBERG, Clement. A Necessidade do Formalismo. In: CORTIM, C.; FERREIRA, G. (Orgs.). Clement Greenberg e o Debate Crítico. Rio de Janeiro: Zahar, 2001, p. 127). Neste sentido, a "realidade" não seria somente nem condição exterior à técnica formal (de uma perspectiva sociológica) nem a coisa representada, mas presente no próprio "conteúdo" formal da obra, na medida em que "sedimentada" nos seus procedimentos formais e técnicos. Na Teoria Estética: "[...] os antagonismos não resolvidos da realidade retornam às obras de arte como os problemas imanentes de sua forma" (ADORNO, Theodor W. Teoria Estética. Lisboa: Edições 70, 1982, p. 16).

${ }^{19}$ FÉLIX, Moacyr. Um Poeta na Cidade e no Tempo. Rio de Janeiro: Civilização Brasileira, 1966, p. 34.

${ }^{20}$ SOUSA, Edson Luiz André de; LIMA, Manoel Ricardo de. O nome que falta. Psicologia $\mathcal{E}$ Sociedade, v. 21, edição especial, 51-56, 2009, p. 51. 
irremediavelmente ${ }^{21}$. Para Sousa e Lima, poesia e utopia se encontram no escape à "captura por uma imagem como um furo na imagem", subtraindo "do sujeito a sensação de que finalmente encontrou a palavra justa, o lugar ideal"22. Em Morro dentro deste..., o poeta morre "dentro deste papel em branco", pois

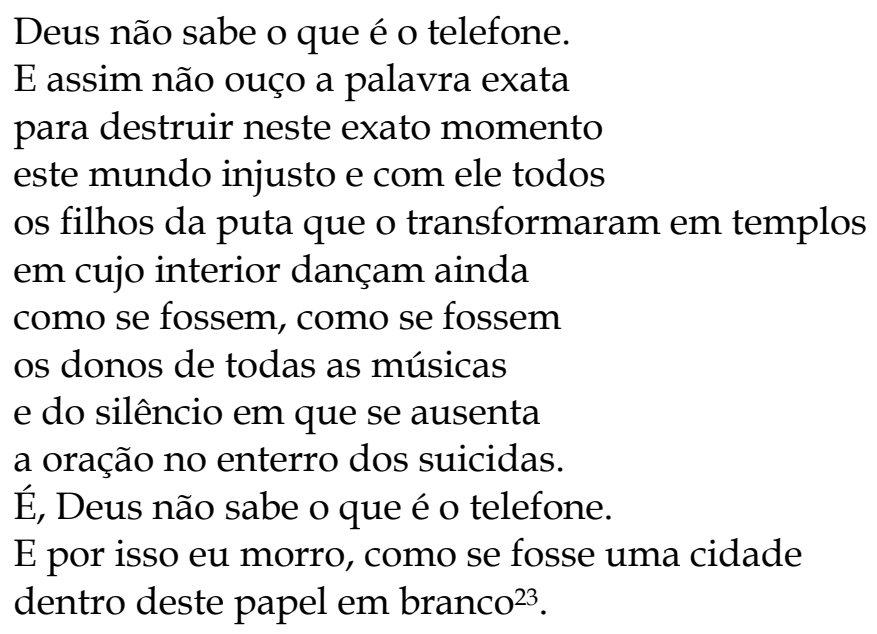

Impossibilitada a reconciliação, escapa ao poeta "a palavra exata". Ele jaz na imensidão vazia do papel em branco, o mesmo que o espera e o guarda como se fosse uma prisão, pois "o papel em branco então serve / como serve ao prisioneiro / a parede branca do cárcere" 24. O poeta está, em relação ao papel em branco, na condição de exilado: na busca incessante da palavra "justa", da imagem "ideal", que reconciliem potência e ato, vida e realidade, "exilado entre palavras que nunca foram proferidas" 25 .

A figura do "exílio" é recorrente nos poemas de Félix. Decerto, o exilado ocupa lugar central na história cultural latino-americana do século XX, uma vez que tantos militantes, artistas e intelectuais tiveram de encontrar destino na saída do seu país natal para poderem se manter vivos, ou sobrevivos. Ainda que Félix não tenha tido que deixar o país durante o Regime Militar (ou civil-militar), tal gesto de "identificação" pode representar, no mínimo, algo como uma empatia por tal condição. Teríamos, assim, por um lado, marcada a diferença entre "sujeito vivente" e "sujeito lírico", este que se anuncia como exilado, e, por outro,

${ }^{21}$ Nos remetemos, aqui, à noção benjaminiana de "imagem dialética" (BENJAMIN, Walter. Passagens. Belo Horizonte: Ed. UFMG; São Paulo: Imprensa Oficial do Estado de São Paulo, 2007, p. 515) e, sobretudo, ao tratamento dado a ela por Didi-Huberman, em específico em Sobrevivência dos vaga-lumes (DIDI-HUBERMAN, Georges. Sobrevivência dos Vaga-Lumes. Belo Horizonte: UFMG, 2011.).

${ }^{22}$ SOUSA, E. L. A.; LIMA, M. R., op. cit., p. 55.

${ }^{23}$ FÉLIX, Moacyr. Em Nome da Vida. Rio de Janeiro: Civilização Brasileira, 1981, p. 59.

${ }^{24}$ Id., Ibid., p. 31.

${ }^{25}$ Id., Ibid., p. 32. 
o ânimo político e estético da poética de Félix: dar voz à expectativa e à frustração, à promessa da liberdade e às violências institucionais através dos "vencidos" - ou, em outros termos, dar voz (ou letras) ao sofrimento produzido pela condição trágica que a promessa da liberdade encena, algo misteriosamente, ao atravessar as vidas dos indivíduos contemporâneos. Como escreveu Adorno, em Minima Moralia, "cabe unirse ao sofrimento das pessoas: o menor passo na direção das suas alegrias segue no rumo de enrijecer o sofrimento" 26 . Na Teoria Estética, podemos ler: "mais vale desejar que um dia melhor a arte desapareça que esquecer o sofrimento, que é a sua expressão [...]. Esse sofrimento é o conteúdo humano que a servidão falsifica em positividade" 27.

Em Canção do Exílio Aqui, de 1977, o poeta buscou "inventariar" seus exílios - exilado no sofrimento do outro, nas promessas que não se cumpriram, na "geração interrompida" da qual fez parte28, até o exílio em si mesmo, ou o des-encontro do "si mesmo" como exílio. Na capa do livro, assinada por Dounê Spinola, vê-se uma figura humana, de face interditada, que com uma mão abre a blusa no peito (revelando uma estrada que se perde no horizonte) e com outra mão aponta, com o indicador em riste, o horizonte. Seguindo a indicação do dedo na imagem, e atentando ao título do livro - Canção do exílio "aqui" -, seria possível conjecturar que "exílio" não seria a representação de um estar "fora", mas um indefinido instaurado na subjetividade do poeta, como caminho ainda-não-percorrido, como condição permanente da ausência de lugar. $\mathrm{O}$ "aqui" do exílio seria o horizonte a despontar e a desaparecer na interioridade - o que a estrada ao interior revela não é uma verdade substancial em-si, mas, ao contrário, o ponto-de-fuga que insinua a promessa de um ponto-de-chegada não claro e não definido, insistentemente em aberto. A linha do horizonte é como uma Utopia: lá está orientando o caminho, mas se afasta tanto mais quanto se anda em sua direção. Nos versos que compõem o livro, Félix é exilado na pedra, no ar, no bar; nos suicídios de Benjamin e de Vargas; exilado nos deuses, nas prostitutas e na gritaria das crianças; exilado nos outros, no Outro, no telefone que não toca, em cartas não enviadas, em nuvens que $o$ dicionário desconhece. Suas estrofes finais:

\footnotetext{
${ }^{26}$ ADORNO, Theodor W. Minima Moralia. Rio de Janeiro: Azougue, 2008, p. 22.

27 Id. Teoria Estética. Lisboa: Edições 70, 1982, p. 291.

${ }^{28}$ O subtítulo do livro é "ou Alguns elementos para o inventário de uma geração nesta cidade do Rio de Janeiro". Na primeira parte da obra, Félix faz um "inventário" daquela que Beatriz Vieira (A Palavra Perplexa. São Paulo: Hucitec, 2011) chamou de "geração interrompida" - sendo "exilado" nos presos políticos, nos perseguidos, desaparecidos e assassinados da sua geração -, mas o livro realiza também "inventário" de um Brasil interrompido, digamos, exilado numa expectativa, ou num projeto de país, que àquela altura já lhe parecia uma promessa não cumprida.
} 
Exilado no exílio de todos os exílios que em mim não findam mais e são eternos.

porque neles morrerei e para sempre no meu tempo morto eles serão

- imutáveis os exílios que sempre foram dentro de mim, quando eu vivia

como a flor que ao ser regada pela sombra lembra as exigências de sol sobre seu caule - e em direção da aurora se prolonga ${ }^{29}$.

Em um poema de juventude, escrito em 1951, chamado Exílio, lemos:

O mundo não era o rosto de minha amada, nem o olhar de minha mãe.

E aquele fim de noite, preso na árvore do amanhã, tão pouco trazia o meu primeiro dia ${ }^{30}$.

O mundo é um lugar estranho - ou, mais que estranho, um desabrigo. No tempo, contudo, é o mundo, como fruto na árvore do amanhã, como um fim de noite que ainda não promete um novo dia. $\mathrm{O}$ próprio mundo é, assim, um lugar de exílio: nele o poeta busca, mas não encontra casa - nem o rosto da amada, nem o olhar da mãe. Desamparado é o poeta, experimentando estar num tempo que é de espera, um tempo de penumbra, indigência e desabrigo, como disse Heidegger, ao definir a modernidade como "uma noite do mundo" 31.

Mas se o "mundo" é um "lugar" a revelar no "exílio" a "topicidade" do poeta, cumpre sublinhar que ele se liga ao tempo e ao espaço, mas não se confunde com eles. O "lugar" [topos], nos diz Agamben, é "algo mais originário que o espaço" 32. Como propõe o filósofo italiano, "a exploração topológica está constantemente orientada sob a luz da utopia", pois, na medida em que qualitativamente diferente do espaço e do tempo, dá acesso ao "irreal" através do qual "será possível apropriarmo-nos da realidade" 33 . Se a "topicidade" do poeta é um mundo em que se lhe afigura o desamparo ${ }^{34}$, o tempo e o espaço, ou seja, as orientações

${ }^{29}$ FÉLIX, Moacyr. Canção do Exílio Aqui. Rio de Janeiro: Civilização Brasileira, 1977, p. 113.

${ }^{30}$ FÉLIX, Moacyr. Invenção de Crença e Descrença. Rio de Janeiro: Civilização Brasileira, 1978, p. 49 .

${ }^{31}$ HEIDEGGER, Martin. Caminos de Bosque. Madrid: Alianza Editorial, 2005, p. 199.

32 AGAMBEN, Giorgio. Estâncias. Belo Horizonte: Autêntica, 2012, p. 15.

33 Id., Ibid.

${ }^{34}$ Desamparo (Hilflosigkeit, em Freud) é uma noção algo polissêmica, tanto em relação aos seus usos por Freud quanto às apropriações que aqueles deram origem. Aqui, pensaremos o 
epistêmicas básicas do sujeito, estão como que suspensos, em um "ainda" reticente.

O poeta está - exilado - em "uma noite do mundo", à espera do anúncio do "primeiro dia". Observe-se que o poeta não diz "trazia de volta o meu primeiro dia". O primeiro dia, que remeteria à origem, é porvir (preso na árvore do amanhã), mas o tempo está, também aí, como num exílio, sem cidadania garantida, numa condição de "ainda-não". $O$ "primeiro dia" de Félix parece fazer eco, assim, à noção de "origem" [Ursprung] como em Benjamin, que "não está situada num passado cronológico" 35 , mas "se localiza no fluxo do vir-a-ser"36. Em outro sentido, talvez complementar, o "primeiro dia", como início da vida, parece permanecer latente, em potência, encontrando asilo "no interior do tempo como os frutos / no interior das árvores", conforme lemos no poema Os Mortos:

No século XX, no mundo
ocidental e cristão, oriental e socialista
enquanto no céu e na terra
a guerra era fria como a pele dos mortos
os vivos estavam asilados
irmanadamente
no interior do tempo como os frutos
no interior das árvores
ou cantavam nas prisões
a necessária esperança ${ }^{37}$

Em Os Mortos, a esperança aparece não a guiar o homem em direção ao futuro, mas como resposta, necessária, à prisão. O papel em branco, o mundo e o século se afiguram como prisões e como exílio. Uma noite do mundo, um mundo de penúria - em que falta "o desocultamento da essência da dor, da morte e do amor", como disse Heidegger -, em que "é perdido o fundamento" 38 . Daí que esta noite do mundo é um abismo ${ }^{39}$.

\footnotetext{
"desamparo" tanto como um "afeto", seguindo a leitura de Vladimir Safatle (O Circuito dos Afetos. Belo Horizonte: Autêntica, 2016), quanto sinônimo de "mal-estar" e de "Real", conforme Christian Dunker (Mal-estar, sofrimento e sintoma. São Paulo: Boitempo, 2014). Tal aproximação ou tal "plasticidade" do termo - é chancelada por ambos autores em suas elaborações. Para uma revisão dos modos como a noção é trabalhada ao longo do pensamento freudiano, ver FORTES, Isabel; SANTOS, Nathália. Desamparo e alteridade: a dupla face do outro. Psicologia USP, v. 22, n. 4, 2011.

${ }^{35}$ AGAMBEN, Giorgio. O que é contemporâneo? Chapecó: Argos, 2009, p. 69.

${ }^{36}$ BENJAMIN, Walter. Origem do drama barroco alemão. São Paulo: Brasiliense, 1986, p. 68.

${ }^{37}$ FÉLIX, Moacyr. Um Poeta na Cidade e no Tempo. Rio de Janeiro: Civilização Brasileira, 1966, p. 24.

${ }^{38}$ HEIDEGGER, op. cit., p. 204.

${ }^{39}$ Id., Ibid., p. 199-200.
} 
Abismo que, como nos disse Wislawa Szymborska, no poema Autonomia, "não nos divide / nos circunda" 40 .

Abismo, penumbra, penúria, carência, estranhamento, desabrigo, desamparo. Um exílio no mundo, ou um mundo que é exílio, é o "lugar" do poeta. Ele não tem pátria - ou, se tem, não a tem. A terra natal, aquela que promete reencontro do indivíduo consigo mesmo, é sempre suspensa, um outro-lugar, de geografia imprecisa. Lhe resta, como pista, fragmentos de memórias e expectativas. Mas essas pistas, esses vestígios, não apontam a um caminho; antes, incitam uma vaga e discreta esperança que o poeta não recusa, mas aceita como sinal de "algo que falta". Não é fugindo do abismo, lutando contra o desamparo, mas fazendo-o falar através de si mesmo que se poderá, como disse Vladimir Safatle, "produzir um gesto de forte potencial libertador" 41 .

Habitante de um mundo que é um lugar-outro, o poeta é, dialeticamente, habitado por uma "ausência" insistentemente presente, por uma pergunta esquecida. Na versão de 1978, o poema Exílio continua: "Fiquei eu, e a presença / de uma pergunta - uma só! - velada / como as memórias de um mar / no vazio das conchas. // E essa pergunta - meu Deus! - eu já esqueci" 42 . Se o poeta está à presença de uma ausência, que ressoa, interrogativa, como marés no vazio das conchas, não chegando a forjar-se como pergunta, é porque o que poderia ser comum, ou familiar, a outrem, ao poeta é inquietante e estranho [Unheimlich]. Daí a intimidade entre o poeta e o utopista afiançada pelo "exílio" como lugar-outro: esse "lugar poético" não está deslocado geograficamente, mas topologicamente - como incitando e permitindo uma condição existencial e/ou uma disposição afetiva. "O inquietante seria sempre algo em que nos achamos desarvorados, por assim dizer"43. Mas essa "disposição afetiva" porta, como todo afeto, uma ambiguidade, nos adverte Freud ela é estranhamente familiar. Signo de uma "realidade ontológica", como disse Paul-Laurent Assoun, que, "exibindo 'alguma coisa', mostra seu segredo, produzindo o invisível no visível [...]. Dando a ver o oculto, manifestando o não manifestável, ela sela a aliança do mistério (Geheimnis) e do revelado (Offenbare)" 44 . Trata-se, pois, de uma "refração subjetiva", como diz o autor, no sujeito e na realidade.

O Exílio de Félix nos reporta, assim, a dois movimentos complementares. Primeiro, àquela condição, descrita por Adorno, de

\footnotetext{
${ }^{40}$ SZYMBORSKA, Wislawa. Um amor feliz. São Paulo: Cia. das Letras, 2016, p. 143-145.

${ }^{41}$ SAFATLE, Vladimir. O Circuito dos Afetos. Belo Horizonte: Autêntica, 2016, p. 18.

${ }^{2}$ FÉLIX, Moacyr. Invenção de Crença e Descrença. Rio de Janeiro: Civilização Brasileira, 1978, p. 49.

${ }^{43}$ FREUD, Sigmund. O Inquietante. In: História de uma neurose infantil ("O homem dos lobos"), Além do princípio do prazer e outros textos (1917-1920). São Paulo: Cia. das Letras, 2010, p. 332.

${ }^{44}$ Paul-Laurent Assoun Apud BRANCO, Guilherme Castelo. O Olhar e o Amor. Rio de Janeiro: Nau, 1995, p. 15-16.
} 
"não estar em casa na própria casa"45, que representaria tanto o "lugar" do intelectual, como aquele que encontrada morada na fronteira, como um náufrago ou como um exilado ${ }^{46}$, quanto a recusa à individuação e à interioridade burguesas, que "embalsama[m] em vida" 47. Segundo, mas de modo complementar, à condição do artista e às condições da criação. Como escreveu Edson Luiz de Sousa, a respeito de A história mais bela do mundo, de Rudyard Kipling:

“Na casa da minha mãe não tem lugar para escrever". Bela passagem que mostra o quanto Charlie [protagonista do conto de Kipling] precisava de um "fora de casa" como lugar de produção. Buscava se afastar desse excesso de familiar. Neste trânsito buscaria uma condição de alteridade e do exílio como condição de possibilidade da obra. Aqui, neste contexto, o familiar é uma espécie de burocratização do amanhã, já que é território do mesmo, de reiteração de circuitos repetitivos ${ }^{48}$.

Para Sousa, todo ato criativo é um ato utópico. E o utópico se apresenta e institui na recusa à resignação diante de um futuro que se insinua como "burocratizado", ou seja, como "mesmidade" e repetição. A recusa ao familiar (ou, então, a ênfase no estranho que habita o familiar) seria um modo de criar aberturas na realidade entendida como prisão, num gesto de negação que acaba por negar, também, a elaboração de uma imagem de transcendência que pudesse representar o Novo, o lugaroutro no futuro. Converge, assim, à afirmativa, marcadamente adorniana, de Fredric Jameson ao dizer que "a utopia é, de alguma forma, negativa, e é tanto mais autêntica quanto menos pudermos imaginá-la" (JAMESON, 2006, p. 274).

Se Heidegger havia respondido a pergunta de Hölderlin, em Pão e Vinho, "para quê poetas em tempos de penumbra?", dizendo que ao poeta cabe expressar "poeticamente a essência da poesia" 49, Félix, que fez de tal interrogação epígrafe do seu livro de 195950 parece respondê-la afirmando seu "ofício maior": "Negar, este é o meu ofício maior / negar o que existe, negá-lo sempre. / Ah, a magia de cada crepúsculo / dentro do

\footnotetext{
${ }^{45}$ ADORNO, Theodor W. Minima Moralia. Rio de Janeiro: Azougue, 2008, p. 35.

46 "Damos como certa a pátria e a língua, elas se tornam natureza, e seus pressupostos subjacentes retrocedem para o dogma e a ortodoxia. [...] O exilado sabe que, num mundo secular, as pátrias são sempre provisórias. Fronteiras e barreiras, que nos fecham na segurança de um território familiar, também podem se tornar prisões e são, com frequência, defendidas para além da razão ou da necessidade. O exilado atravessa fronteiras, rompe barreiras do pensamento e da experiência" (SAID, Edward W. Reflexões sobre o exílio e outros ensaios. São Paulo: Cia. das Letras, 2003, p. 58).

47 ADORNO, Theodor W. Minima Moralia. Rio de Janeiro: Azougue, 2008, p. 35.

${ }^{48}$ SOUSA, Edson Luiz André de. A burocratização do amanhã. Revista Porto Alegre, v. 14, n. 24, maio de 2008, p. 43-44.

${ }^{49}$ HEIDEGGER, op. cit., p. 201-202.

${ }^{50}$ FÉLIX, Moacyr. O Pão e o Vinho. Rio de Janeiro: Antunes \& Cia., 1959.
} 
olho em que reside / teimosa, a luz inexistente de uma aurora!" 51 . O poeta como utopista afirma seu não-lugar em relação ao existente, como se a "essência da poesia" fosse o negativo dialético da realidade histórica, o "não-ente", nos termos de Adorno52, e tal posição a condição para a Esperança - uma luz inexistente, todavia teimosa, que sinaliza a aurora. Pois, se em Bloch a "aurora" sinaliza ao porvir que está, a todo instante, irrompendo no presente, guiada pela Esperança e pela "intuição objetiva do que-ainda-não-veio-a-ser como de algo que ainda-não-se-tornou-bom" 53, em Félix é preciso "destruir este mundo em que as auroras / se asilam / e nos condenam"54. Na penumbra, num "lugar" que é "sem fundamento", a "função da utopia" seria menos a de imaginar um futuro que transcenda a precariedade do presente, mas a de "denunciar", por assim dizer, "nossa completa incapacidade de imaginar tal futuro, ou seja, nossa prisão em um presente não-utópico sem historicidade nem futuro" 55 .

Façamos uma breve retomada do que elaboramos até aqui. A partir de Ernst Bloch, o utópico é compreendido como um impulso - ou desejo - que, manifesto primeiramente no sonho diurno, se direciona a "um outro lugar". Este "lugar-outro" (u-topos) é, para Bloch, o futuro. O desejo (que, como falta, sinaliza a presença da carência), a elaboração/projeção imagética que opera o sonho diurno e a passagem do sonho à Utopia concreta, através da mediação da "materialidade da imagem onírica" com a realidade objetiva, constituem o movimento da dialética da Esperança. A partir da Utopia concreta, a transformação do mundo pela práxis revolucionária: destruir o mundo em que vigora a carência e construir um mundo em que as demandas humanas (para Bloch, genuinamente inclinadas ao bem) possam ser reconhecidas e realizadas. A poética utópica de Félix se situa, assim entendemos, entre o primeiro e o segundo movimentos da dialética da Esperança, conforme desenhada por Pierre Furter ${ }^{56}$ : entre a presença da carência, ou seja, do desejo, e a projeção imagética do sonho utópico num "possível-real". Pressupondo que o sonho (a imagem do desejo) tenha relação direta com o que chamamos de estado de carência, ele se faz presente, mas frustrada está sua representatividade, ou sua "aparição", enquanto imagem capaz de orientar, no horizonte possível do tempo histórico, a reconciliação. Sua

\footnotetext{
${ }^{51}$ Id. Em Nome da Vida. Rio de Janeiro: Civilização Brasileira, 1981, p. 65.

${ }^{52}$ ADORNO, T. W. Teoria Estética. Lisboa: Edições 70, 1982, p. 208.

${ }^{53} \mathrm{BLOCH}$, Ernst. op. cit., p. 144.

${ }^{54}$ FÉLIX, Moacyr. Um Poeta na Cidade e no Tempo. Rio de Janeiro: Civilização Brasileira, 1966, p. 33.

${ }^{55}$ JAMESON, Fredric. Espaço e Imagem. Rio de Janeiro: UFRJ, 2006, p. 274.

${ }^{56}$ FURTER, Pierre. op. cit.
} 
utopia está, assim, como que em "exílio" - à espera, tencionando, ou dialetizando, no "limite" 57 , a própria Esperança.

A poética utópica do exílio entre o desejo e o sonho não subtrai da imagem do futuro sua potencial capacidade política e contestatória, mas instaura uma crise na possibilidade mesma de dizê-la: uma poética voltada ao "ser que ainda não fomos e que em sonho nos reinventa" 58 , e que insiste na negatividade do "ainda não". Trata-se, assim, de uma utopia que não supera o desamparo, mas que o aprofunda, como se somente através de uma intimidade indizível com ele fosse possível produzir afetos efetivamente subversivos, como nos orienta Safatle ${ }^{59}$; como se somente através de uma apropriação da sua mais íntima impropriedade, como nos termos de Agamben ${ }^{60}$, o sujeito pudesse aparecer como um rastro informe, ou como "a sombra de um sonho de poeta". Vejamos o poema Auto-retrato, em sua versão de 1992:

\author{
Certa vez, num aventura \\ estranha, fugi \\ dos estreitos horários \\ em que me estorcia \\ para uma ampliação sem fim. \\ Quando voltei, \\ e senti, de novo, ferindo-me \\ o peso dos grilhões, \\ então não mais sabia quem eu era. \\ E nunca mais soube quem eu sou. \\ Talvez a sombra triste de um \\ sonho de poeta. \\ Talvez a misteriosa alma \\ de uma estrela \\ a guarda ainda no profundo \\ cerne a ilógica saudade \\ de um passado astral ${ }^{61}$.
}

Estreitos horários ferem como grilhões pesados. Ferem, aprisionam e, com efeito, impedem saber "quem eu sou". Somente na fuga da hora, ou seja, na liberdade dos grilhões, na "ampliação sem fim", é possível

\footnotetext{
${ }^{57} \mathrm{Na}$ Ciência da Lógica, a noção de "limite" se refere ao "meio", ou ao cerne, da contradição dialética. "Algo é, portanto, como ser aí imediato, o limite frente a outro algo, mas ele tem o limite nele mesmo e é algo através da mediação do limite, que é igualmente seu não ser. O limite é a mediação através da qual algo e outro tanto são quanto não são" (HEGEL, G. W. F. Ciência da Lógica. 1. A doutrina do Ser. Petrópolis: Vozes; Bragança Paulista: Ed. São Francisco, 2016, p. 131).

${ }^{58}$ FÉLIX, Moacyr. Em Nome da Vida. Rio de Janeiro: Civilização Brasileira, 1981, p. 51.

${ }^{59}$ SAFATLE, Vladimir. O Circuito dos Afetos. Belo Horizonte: Autêntica, 2016.

${ }^{60}$ AGAMBEN, Giorgio. A Comunidade que vem. Belo Horizonte: Autêntica, 2013.

${ }^{61}$ FÉLIX, Moacyr. O Pensar e o Sentir na Obra de Moacyr Félix. Rio de Janeiro: Fundação Biblioteca Nacional; Bertrand Brasil, 2002, p. 79.
} 
encontrar-se. Todavia, de volta à hora, o que resta é a sombra triste, melancólica e nostálgica de um passado incerto. Na versão de 1993, há uma alteração no poema: é "do estreito túmulo" que foge o poeta62. Como escravo que pena ao peso dos grilhões, desencontrado de si mesmo, o poeta não vê a "estreiteza" da realidade senão como lugar que abriga a morte. Escravo do tempo, portanto, lhe resta de liberdade - ou de vida uma ilógica saudade.

É significativo que o poema em questão se intitule Auto-retrato. O poeta não é capaz de representar sua própria face senão através da angústia da luta pelo auto reconhecimento, brevemente sinalizada, fragilmente permitida, por uma fagulha de saudade que é "ilógica". No cerne da tentativa de re-conhecer a si mesmo está instaurado o conflito entre a consciência da dissolução da experiência provocada pela vida moderna e o esforço da elaboração de uma negação desta crise, na representação de uma plenitude em que os grilhões da vida hodierna são ausentes.

O estranhamento de si mesmo pode ser lido como uma crise no "familiar", mas também como uma crítica ao "si mesmo". Ao escapar ao retrato de si, o poeta estaria pondo em cena a urgência da elaboração de formas de reconhecimento "antipredicativas"63, ou seja, em que a individualidade não se portasse como proprietária de si mesma, mas como imagem opaca, no limite irrealizável, diante de uma "ampliação sem fim" acessada unicamente através do significante "estranho" ("uma estranha aventura", nos diz Félix). Se considerarmos que a "pedra de toque" do liberalismo é a "evidente" (sic.) posse que o indivíduo tem de si mesmo, como quis Locke, ao dizer que "cada homem tem uma propriedade particular em sua própria pessoa"64, então uma crítica radical ao capitalismo haveria de visar esse dado evidente. "[...] então não mais sabia quem eu era. / E nunca mais soube quem eu sou": perdido está não tanto o "si mesmo", mas a certeza deste "si mesmo".

Se o máximo que Félix nos oferece daquela "aventura" a uma "ampliação sem fim" é que ela é "estranha", talvez seja por conta do seu caráter inominável, e, por extensão, "inimageável". Encontramos, aqui, a característica "essencial" do desejo, qual seja, ser justamente desprovido de qualquer "essência" predicável - sem nome próprio e "fundamentalmente inadequado a toda figuração"65. O caráter negativo do desejo se acha com o "ofício maior" do poeta, que é "um agente de

\footnotetext{
${ }^{62}$ FÉLIX, Moacyr. Antologia Poética. Rio de Janeiro: José Olympio, 1993, p. 153.

${ }^{63}$ SAFATLE, Vladimir. O Circuito dos Afetos. Belo Horizonte: Autêntica, 2016.

${ }^{64}$ LOCKE, John. Segundo tratado sobre o governo. São Paulo: Martin Claret, 2002, p. 38.

${ }^{65}$ SAFATLE, Vladimir. Introdução a Jacques Lacan. Belo Horizonte: Autêntica, 2017, p. 51.
} 
negação" 66 , instituindo o desafio de encontrar palavras - que evoquem ou criem imagens - sem que o próprio desejo se confunda com as fantasias (ou imagens) que tentam lhe emprestar uma forma ou uma cena. Sustentar o desejo significaria sustentar sua negatividade, de modo que apresentar um "autorretrato" implicaria empreender o desafio de "reconhecer a si mesmo naquilo que não se conforma à imagem" 67 .

Tanto a imagem do futuro quanto a imagem de si respondem ao desamparo de modo a oferecer um suporte imaginário, um "amparo", ou mesmo um "anteparo", à insistente força "descentradora" e disruptiva do desejo. Com efeito, o mesmo pode ser dito em relação ao passado, sobretudo a um passado idealizado. No Auto-retrato, o passado igualmente não tem forma nem nome: remanesce dele uma saudade "ilógica", "astral", "misteriosa". Um passado, portanto, que não passou, e assombra melancolicamente o presente na tentativa de fixar uma identidade - melancolicamente posto que a perda da certeza do si mesmo é perda da capacidade de dizer exatamente "o que não é" e/ou o que foi perdido ${ }^{68}$. Em vez de elaborar uma nova imagem ou de escapar ao confronto com a incerteza, o poeta insiste na primeira pessoa - mas uma primeira pessoa que se diz "desapropriada" dos seus predicados, ou, então, apropriando-se da sua impropriedade.

A leitura oferecida por Marcelo Ridenti69 do "romantismo revolucionário" - tomado como "fio condutor" (sic.) para compreensão das produções culturais e artísticas da "esquerda" brasileira, em específico as que tomaram corpo a partir do final da década de 1950 pode assinalar, na poesia de Moacyr Félix, um movimento de crítica (ou de autocrítica) da modernidade (ou do capitalismo) ${ }^{70}$. Vejamos os traços

\footnotetext{
${ }^{66}$ FÉLIX, Moacyr. O Pensar e o Sentir na Obra de Moacyr Félix. Rio de Janeiro: Fundação Biblioteca Nacional; Bertrand Brasil, 2002, p. 85.

${ }^{67}$ SAFATLE, Vladimir. Introdução a Jacques Lacan. Belo Horizonte: Autêntica, 2017, p. 41.

${ }_{68}$ Como diz Judith Butler, ao retomar Luto e Melancolia e O Eu e o Isso, "Freud observa que, no luto, o objeto é 'declarado' perdido ou morto, mas segue-se que, na melancolia, nenhuma declaração é possível. Como perda anterior à fala e à declaração, ela é a condição limitante de sua possibilidade: um recuo ou retração da fala que torna a fala possível. Neste sentido, a melancolia torna o luto possível [...]". (BUTLER, Judith. A vida psíquica do poder. Belo Horizonte: Autêntica, 2017, p. 178). De acordo com Butler, a melancolia sinaliza a perda da capacidade de identificar o que se perdeu em um "objeto" identificado como "perdido" - se todo objeto de identificação é suporte especular do Eu, o que se perde, naquilo que se perde, é algo do próprio Eu que "desconhece" seu caráter essencialmente alienado. Ela sinaliza, assim, a um resto "inelutável" sendo, ao mesmo tempo, condição para o luto.

${ }^{69}$ RIDENTI, Marcelo. Em busca do povo brasileiro. São Paulo; Rio de Janeiro: Record, 2000.

${ }^{70}$ Embora Ridenti não trate especificamente da poesia de Moacyr Félix, cumpre observar a nota escrita por Michel Löwy que figura na contracapa do livro: “O que será que canta nas músicas de Caetano Veloso e Chico Buarque, murmura nos poemas de Ferreira Gullar e Moacyr Félix, grita nos dramas do Teatro de Arena e no Oficina, dança nos filmes de Cacá Diegues e Glauber Rocha, manda chumbo com Carlos Marighella e o capitão Lamarca, pinta quadros numa cela do presídio Tiradentes, morre na contramão atrapalhando o trânsito? A resposta para a charada
} 
do "romantismo revolucionário": uma inadequação da "alma" (como uma potência da vida) à realidade; a defesa da subjetividade como "forma de resistência à reificação" - uma "revolta da subjetividade e da afetividade reprimidas, canalizadas e deformadas"; a presença de um ideal, um "paraíso perdido" que corresponda à "plenitude do todo humano e natural"; o vínculo da crítica (ou da autocrítica) à "experiência de uma perda", o "senso agudo da alienação, frequentemente vivido como exílio"71. Em suma, o "romantismo revolucionário" parece denunciar a alienação (ou a perda) da singularidade individual, buscando num passado idealizado orientações imagéticas para a projeção de um futuro - "modernizador", diz Ridenti72 - de reconciliação (sobretudo, de reconciliação entre as potências subjetivas e a realidade).

A crença na subjetividade como individualidade autônoma é moderna, e, neste sentido, uma imagem utópica de reconciliação entre individualidade e realidade (ou a imagem utópica de uma realidade que permita à individualidade realizar-se como autônoma, não-alienada) pode ser chamada de "modernizadora". Todavia, os termos seriam contrários se a crítica à modernidade (ou ao capitalismo) não a acusasse de "realidade alienante", mas, ao contrário, como responsável pela instituição mesma da expectativa de realização de uma individualidade "plena", "autêntica" e "autônoma". Estaríamos, assim, diante de uma crítica ou "dialética" ou "trágica" da modernidade, como aquela que, a partir de Hegel e de Freud, nos oferece Adorno, e não exatamente "romântica". Nesta crítica, a modernidade não instituiria uma realidade que privaria o sujeito de si mesmo, mas uma realidade dependente da promessa (ou da ilusão, enfim, ideológica) da realização daquela concepção de sujeito, animada por uma espécie de imperativo a dizer que o sujeito deveria ter propriedade sobre si mesmo (ou sobre a "sua" individualidade).

É certo que a figura do "homem do povo", eleita por Ridenti (2000) como aquela que materializa o "passado ideal perdido" para a arte de esquerda brasileira, aparece em poemas de Félix, em específico aqueles escritos durante sua inserção no CPC da UNE, no início dos anos 1960. O poema $E u$ vi talvez nos ofereça o melhor exemplo desta marca na poesia de Félix. Nele, o poeta apresenta “o povo" como ingênuo e portador de "uma força que não se sabe força" 73. A marca desta "historicidade" na sua "poética utópica" é, pois, uma marca institucional. Não se pretende,

está neste livro: o romantismo revolucionário" (LÖWY, Michael. Contracapa. In: RIDENTI, Marcelo. op. cit.).

${ }^{71}$ LÖWY, Michael; SAYRÉ, Robert. Revolta e Melancolia. São Paulo: Boitempo, 2015, p. 41-47-4943.

72 RIDENTI, Marcelo. op. cit., p. 25.

${ }^{73}$ FÉLIX, Moacyr. Em Nome da Vida. Rio de Janeiro: Civilização Brasileira, 1981, p. 36. 
assim, refutar a tese de Ridenti, mas oferecer, todavia, uma dúvida sobre a possibilidade de o termo "romantismo revolucionário" abarcar, como um todo, a obra poética de Félix. Que tal marca "institucional" esteja presente em seu espólio poético, parece-nos que constitua algo como um traço secundário nas suas inquietações e elaborações. Nem do futuro nem do passado provêm imagens que sustentem uma crítica ao presente: aquilo que fala do que "não foi" é intimamente "estranho". O seu "exílio" não sinaliza propriamente a uma privação imposta por dispositivos coercitivos, mas oferece nome à sua condição de poeta e utopista: excêntrico em relação a si mesmo e à realidade objetiva.

A subjetividade alienada é tratada de modo manifesto em poemas em que Félix se confronta com espelhos. Via de regra, é um vazio angustiante o que os espelhos lhe devolvem. Em O Texto, "no chão da história o rosto que não tenho, o rosto / que me negam e no qual, no entanto, sou e não poderei deixar de ser / a ausência que corrói as imagens do nosso mundo em todos os espelhos"74. Se, por um lado, alguém lhe nega o rosto próprio - e, aqui, poderíamos vislumbrar uma crítica "romântica" à alienação - por outro, "sou e não poderei deixar de ser" a opacidade deste mesmo rosto, esta "ausência" com a qual não se pode identificar e, ao mesmo tempo, deixar de identificar. Talvez essa ausência fale menos da individualidade moderna que da subjetividade do poeta (ou, mais especificamente, do poeta lírico após Baudelaire): aquele que, de acordo com Agamben, tenta fazer do vazio da experiência - ou, mais propriamente, o "inexperienciável" - uma possibilidade de experiência ${ }^{75}$. Ou, de modo complementar, como aquele que faz da afirmação de si uma experiência de "despersonificação": um Eu que se diz e desaparece ao mesmo instante ${ }^{76}$. Em $O$ Poeta, Félix nos diz que "O poeta se perdia em palavras. / O poeta se perdia nele próprio / sem que espelho algum lhe trouxesse / o que dele assim ex-fato se perdia"77. Ora, o poeta se lança na alienação de si, se lança ao desamparo, sem qualquer compensação ou expectativa de, assim, lhe serem restituídos seus predicados e sua certeza de si. "Em suas molduras douradas os espelhos / mais uma vez /ofereceram seus túmulos sem fundo // Túmulo, túmulo é a lei que rói / entre meus ossos verdades impossíveis"78.

"Mais uma vez", diz o poeta - há algo que "insiste", que se repete e irrompe na imagem desconfigurando a identificação. De "impossível" elaboração talvez seja o próprio desamparo, enquanto condição -

\footnotetext{
74 Id., Ibid., p. 130.

75 AGAMBEN, Giorgio. Infância e História. Belo Horizonte: UFMG, 2005.

76 BLANCHOT, Maurice. O Espaço Literário. São Paulo: Ed. Rocco, 2010.

${ }^{77}$ FÉLIX, Moacyr. Em Nome da Vida. Rio de Janeiro: Civilização Brasileira, 1981, p. 30.

78 Id. Canção do Exílio Aqui. Rio de Janeiro: Civilização Brasileira, 1977, p. 83.
} 
estrutural e resistente à nomeação - de "estar não"79, sinalizada pela presença de uma ausência ou pela presença da "morte" como "o impensável". Todavia, sendo o "túmulo" a "lei" que presentifica o "impossível" na tentativa de reconhecimento da própria imagem (ou da imagem de si como propriedade), talvez a morte nos fale sobre o vazio de significado que jaz além (ou aquém) de qualquer palavra. A "lei" corresponde ao símbolo, ou à linguagem, como nos diz Lacan em seus primeiros anos de ensino: a palavra (o símbolo, a linguagem) é a morte da coisa ${ }^{80}$, instaurando o homem num mundo de ausência/presença, de ser/não-ser, "além" da imagem unificadora e identitária do Eu. Em Quinteto de outono:
No fundo do prato havia um rosto que eu nunca pude decifrar.
Além de mim, no entanto, ele era o meu rosto, o rosto em que nem sequer me encontrei como quem cumpre, de fato, a sua própria lei ${ }^{81}$.

A "lei", ora, a linguagem, que faz do "mundo" um horizonte de "sentido", cinde o sujeito, na medida em que ela aponta também ao "além" do Eu (nos primeiros Seminários de Lacan, a "morte", mas também o desejo). Cumprindo a "lei", o sujeito não pode identificar-se com seu rosto senão mantendo com ele uma relação de desconhecimento, ora, não sem resíduos - presentes/ausentes - que escapam à imagem. $\mathrm{O}$ "além" é presente na imagem como "furo" - por onde insiste o desejo.

Em seu seminário dedicado à "angústia", Lacan82 atenta ao "engodo" que é o objeto imagético e visual do desejo, afirmando sua "verdade" unicamente no afeto: na angústia. Para dar conta da "verdade impossível" do desejo cumpriria duvidar da imagem e apostar na angústia como "verdade" - verdade que não cabe na imagem e que escapa ao significado. Em busca da "verdade" que não seja a da imagem de um mundo "reconciliado com a não-verdade da vida mutilada", o poeta está habitado pela angústia e exilado em palavras nunca ditas, impossíveis, num mundo que não é nem o rosto da amada, nem o olhar da mãe, preso que está na "árvore" do tempo.

Uma utopia comprometida com o desejo e atenta não somente à precariedade da realidade presente, mas também à da subjetividade, reconheceria o sempre insuficiente esforço da imageação (de si e do porvir) e da nomeação. Tal utopia seria, pois, uma "crítica" da realidade a levar adiante o sentido etimológico do termo: crítica como fratura,

\footnotetext{
${ }^{79}$ DUNKER, Christian, op. cit.

${ }^{80}$ LACAN, Jacques. O Seminário. Livro 1. Rio de Janeiro: Zahar, 2009, p. 229.

${ }^{81}$ FÉLIX, Moacyr. Antologia Poética. Rio de Janeiro: José Olympio, 1993, p. 27.

82 LACAN, Jacques. O Seminário. Livro 10. Rio de Janeiro: Zahar, 2005.
} 
quebra, descontinuidade. Uma "crítica" da realidade a pô-la em "crise" seria aquela a "construir perspectivas em que o mundo" apareceria "alheado, com suas fissuras e fendas à mostra" 83 . Ao mesmo tempo, uma "crítica" da subjetividade como "crise" da linguagem enquanto "jogo aberto onde não há assimilação do sujeito ao mundo" 84 . Neste "jogo", a poesia está comprometida como que em um desafio que é, ao mesmo tempo, sua oportunidade: presentificar o desejo sem sugerir sua "realização". Pois o desejo, diz Lacan, no Seminário 2, "é desejo de nada que possa ser nomeado". Todavia, ele prossegue, se o desejo não está "já dado", se é efeito da entrada do sujeito no universo simbólico, "ao nomeá-lo [nomear o desejo], o sujeito cria, faz surgir uma nova presença no mundo" 85 . Na sua insuficiência de dizer o desejo, que não pode prescindir da própria linguagem, ela é "aberta à fecundidade, que é a esperança do sujeito em seu porvir" 86.

\footnotetext{
${ }^{83}$ ADORNO, Theodor W. Minima Moralia. Rio de Janeiro: Azougue, 2008, p. 245.

${ }^{84}$ BRANCO, Guilherme Castelo. op. cit., p. 43.

${ }^{85}$ LACAN, Jacques. O Seminário. Livro 2. Rio de Janeiro: Zahar, 2010, p. 302-309.

${ }^{86}$ BRANCO, Guilherme Castelo. op. cit., p. 43.
} 